\title{
Analysis of Growth Patterns of Islamic Boarding School Business Architecture
}

\author{
Selvi Dwi Granita*, Vika Anindya Kristi**, Sonia Desy Asyarofi***, Muhammad Ainul Yaqin**** \\ Informatic Engineering Department, Faculty of Science and Technology, UIN Maulana Malik Ibrahim Malang, \\ Jl. Gajayana No. 50 Malang 65144, Indonesia. Tel. +62-341-551354 \\ Email: selvigranita@gmail.com*, vikaanindya11@gmail.com**, sonia.desya22@gmail.com***, yaqinov@ti.uin-malang.ac.id****
}

\begin{abstract}
The growth pattern of boarding schools is the process of growing boarding schools from the simplest type to the highest type so as to produce more complex business processes. The growth of business processes can affect the growing needs of Islamic boarding schools. Currently there is no modeling of the growth patterns of Islamic boarding schools, so that the needs of Islamic boarding schools have not been well predicted. Therefore, an analysis of the growth patterns of business architecture in Islamic boarding schools is made so that the growth of Islamic boarding school business architecture can be well predicted. Analysis of the growth pattern of the business architecture of this Islamic boarding school uses cellular automata analysis methods. The parameter that triggers growth is the number of students, from this number can trigger other growth such as the number of teachers, the number of dormitories, the number of staff and several other supporting facilities. The final results obtained from this study are a form of growth patterns in boarding school business architecture represented in the form of graphs that can provide information to be used as academic guidelines in the growth of boarding school business architecture needs.
\end{abstract}

Keywords: Business Architecture, Cellular Automata, Growth in Islamic Boarding Schools, Growth Patterns, Islamic Boarding Schools

\section{INTRODUCTION}

Islamic boarding school is an Islamic educational institution where students live together and study under the guidance of the clerics. Based on 2003 Ministry of Religion standards, Islamic boarding schools are divided into several types. The type of pondok pesantren starts from the simplest to the highest type. Type A or the simplest type consisting of Islamic boarding schools that do not yet have a dormitory, there are only teaching and learning processes carried out by santri and "kyai", type $\mathrm{B}$ has begun to add class facilities, type $\mathrm{C}$ or the highest type of developing pondok pondok that already has dormitories as santri residences, several classrooms for santri learning facilities and have more complex business processes. Islamic boarding school which discusses the type of minimum standard Islamic boarding school. The growth pattern of boarding schools is the process of growing boarding schools from assemblies into large boarding schools. One of the parameters that led to the growth of boarding schools is the number of students (santri), things that can improve facilities, resources and business development processes that occur in boarding schools. The scale of the business process model is proportional to the scale of the organization that runs it. Small scale organizations will run business processes on a small scale, and vice versa large organizations will run business processes on a large scale and more complex. As the organization grows, the scale of business processes will also increase. A growing business process model is a scalable business process model (Ainul Yaqin et al, 2019).
Islamic boarding school is a very complicated organization, and therefore it is necessary to analyze the growth pattern of Islamic boarding school associated with differences in the number of students, teaching staff and infrastructure that can be minimized. Regarding the needs of Islamic boarding schools related to both physical and non-physical development and fulfillment of needs and income. The difference in the growth of school needs in each aspect forms a pattern of growth which can be classified in certain differences to determine the relative growth potential of Islamic boarding schools which can be seen by using Cellular Automata analysis.

Cellular automata is a discrete dynamical system in which space is divided into cellular spatial space and time proceeds at each different stage. Every cell in this system has one condition, where this condition will always be updated according to local rules, the time allotted, the condition itself, and the state of its neighbors in the previous moment (Wolfram, 1984). According to research conducted by Slimi, R. et al (2009) gathering the intention of modeling cellular automata is a promising tool for discussing complex systems and analytical concepts related to power distribution.

Therefore, the researchers support the analysis of school needs growth patterns using the Cellular Automata analysis method to produce a growth pattern of boarding school needs that can provide information as an academic guide in the development of boarding schools. 


\section{MATERIALS AND METHODS}

\section{Study Area}

The object of this study is a boarding school. Each boarding school has a business architecture that is covered according to the standards of the boarding school. In this study using the cellular automata method. The cellular automata method explains that each node has a value so that it can generate a new node.

\section{Procedures}

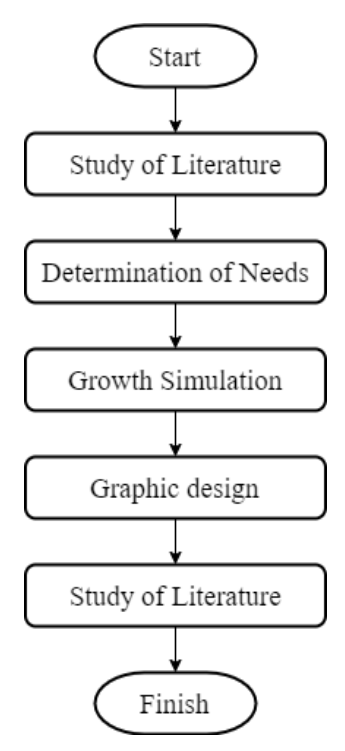

Figure 1. Flowchart.

Figure 1 is the flow of this research, begins the study of literature taken from papers, books and websites relating to the minimum standards of boarding schools and business architecture of boarding schools. After the literature study then determines what needs are needed in this study, after the needs are met then proceed to the growth simulation process of boarding schools and graph design in graph design is a process that triggers the development of boarding schools, then analyzed the ratio between the number of students and business processes.

\section{Data Analysis}

Data analysis in this study as follows:

Table 1. Data Requirements.

\begin{tabular}{ll}
\hline Accommodation & Bathroom \\
& Class \\
& Dormitory/Room \\
& Instructor \\
& Fasilities \\
Health & Officer \\
& Chef (cooks / Kitchener) \\
Consumption & Seller \\
& Security officer \\
\hline
\end{tabular}

Based on the standard of Islamic boarding school the data needed is in the form of boarding school accommodation (bathrooms, places of study / classes, dormitories / residences of students and teachers), health for students Inccordance with the minimum standard of Islamic boarding school, the data needed is: (facilities and officers), consumption for students (cooks and traders) and security for santri.

Table 2. Table Needs for Islamic Boarding School Accommodation.

\begin{tabular}{lcccc}
\hline \multicolumn{5}{c}{ Accommodation } \\
\hline Total Santri & Bathroom & Class & $\begin{array}{c}\text { Dormitory/ } \\
\text { Room }\end{array}$ & Teacher \\
\hline 25 santri & 3 & 1 & 0 & 1 \\
50 santri & 5 & 2 & 0 & 2 \\
75 santri & 8 & 3 & 3 & 3 \\
100 santri & 10 & 4 & 4 & 4 \\
125 santri & 13 & 5 & 5 & 5 \\
150 santri & 15 & 6 & 6 & 6 \\
175 santri & 18 & 7 & 7 & 7 \\
200 santri & 20 & 8 & 8 & 8 \\
\hline
\end{tabular}

Explanation from the table 2 each bathroom can accommodate 10 students, 1 place to study / class can accommodate 20-25 students, for dormitory / residence for type A (number of students 25-50) there is no dormitory available, so students have not lived in boarding schools because new boarding schools are formed in type $\mathrm{C}$ and for teachers 1 instructor can handle a maximum of 25 students.

Table 3. Table of Health Needs in Islamic Boarding Schools.

\begin{tabular}{lll}
\hline & \multicolumn{1}{c}{ Health } \\
\hline Total santri & Facilities & Officer \\
\hline 25 santri & 0 & 0 \\
50 santri & 1 (bed) UKS & 1 \\
75 santri & 1 (bed) UKS & 3 \\
100 santri & 2 (bed) UKS & 4 \\
125 santri & 1 clinic & 5 \\
150 santri & 1 ambulance & \\
& 1 clinic & 6 \\
175 santri & 1 clinic & 7 \\
& 1 ambulance & \\
200 santri & 1 clinic & 8 \\
& & 1 ambulance \\
\hline
\end{tabular}

Explanation from the table 2, type A (number of students 25) facilities are not yet available, in types B and $\mathrm{C}$ health facilities and health workers are available in accordance with the number of students. 1 medical officer can handle 50 students. 
Table 4. Table Consumption Needs of Islamic Boarding Schools.

\begin{tabular}{lll}
\hline & Consumption & \\
\hline Total Santri & Chef $($ cooks $)$ & Seller \\
\hline 25 santri & 0 & 0 \\
50 santri & 0 & 1 \\
75 santri & 1 & 1 \\
100 santri & 2 & 2 \\
125 santri & 2 & 2 \\
\hline
\end{tabular}

\begin{tabular}{lll}
\hline & Consumption & \\
\hline Total Santri & Chef $($ cooks $)$ & Seller \\
\hline 150 santri & 3 & 3 \\
175 santri & 3 & 3 \\
200 santri & 4 & 4 \\
\hline
\end{tabular}

Explanation from the table 4, type A and type B santri do not stay or go home, so they do not get consumption only allows traders to sell in the TPQ / Madrasah Diniyah area, for type C 1 cooks (kitchener) can cook for 75 santri.

Table 5. Table of Security Needs of Islamic Boarding Schools.

\begin{tabular}{lc}
\hline & Security \\
\hline Total santri & Security officer \\
\hline 25 santri & 0 \\
50 santri & 2 \\
75 santri & 3 \\
100 santri & 4 \\
125 santri & 5 \\
150 santri & 6 \\
175 santri & 7 \\
200 santri & 8 \\
\hline
\end{tabular}

Explanation of the table 4, type $\mathrm{A}$ is not available for security officers for students, security is supervised by a kyai/ teacher. Type B security guards are available, 1 security officer can handle 25 students.

\section{RESULTS AND DISCUSSION}

\section{Boarding School type "A"}

Based on the following data analysis, the results of the discussion are in the form of a graph of the growth of Islamic boarding school business architecture:

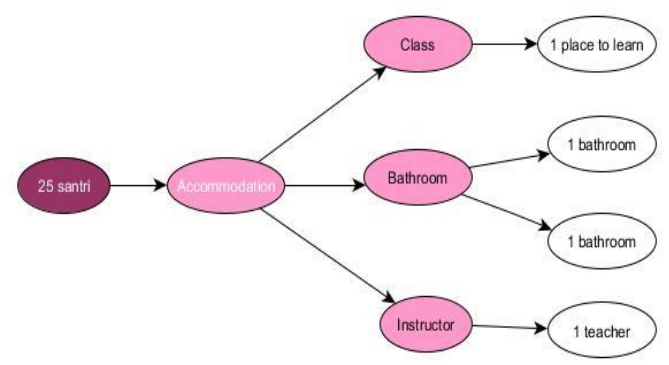

Figure 2. Graph of the growth of boarding school type A.
Based on graph 1 in Figure 2, it can be seen that the growth of boarding school type A starts from the number of students as many as 25 children with accommodation facilities in the form of 1 bathroom and 1 place to study or class. As for the teaching staff of 1 person (teacher / kyai). So the ratio between teachers and students is 1:20 and the ratio between accommodations and students is also at 1: 20.

\section{Boarding School type "B"}

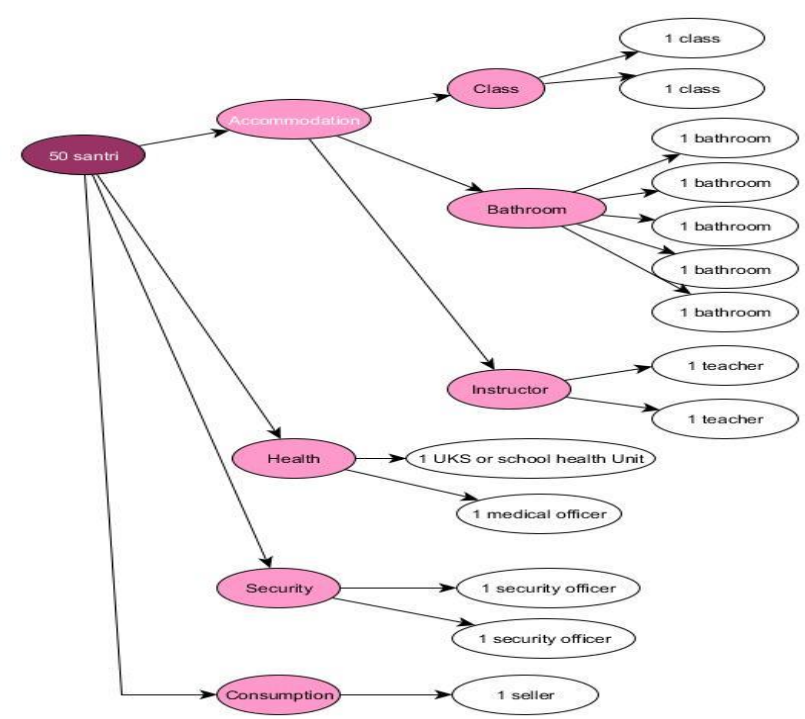

Figure 3. Graph of the growth of boarding school type B.

Based on graph 2 in Figure 3, the growth of boarding school type $\mathrm{B}$ began to increase in the number of students as many as 26-50 students. For accommodation facilities increased to 2 bathrooms and 2 classes. There are 3 lecturers for 3 students. In the health sector there are 1 UKS and 1 medical staff for 50 students. While the security sector consists of 3 security officers for 50 students. So the ratio formed is as follows:

1. The ratio between accommodation and students is 1 : 25.

2. The ratio between teachers and students is $3: 50$.

3. The ratio between UKS and students is 1: 50 .

4. The ratio between medical personnel and students is 1: 50 .

The ratio between security officers and students is 3:50. 


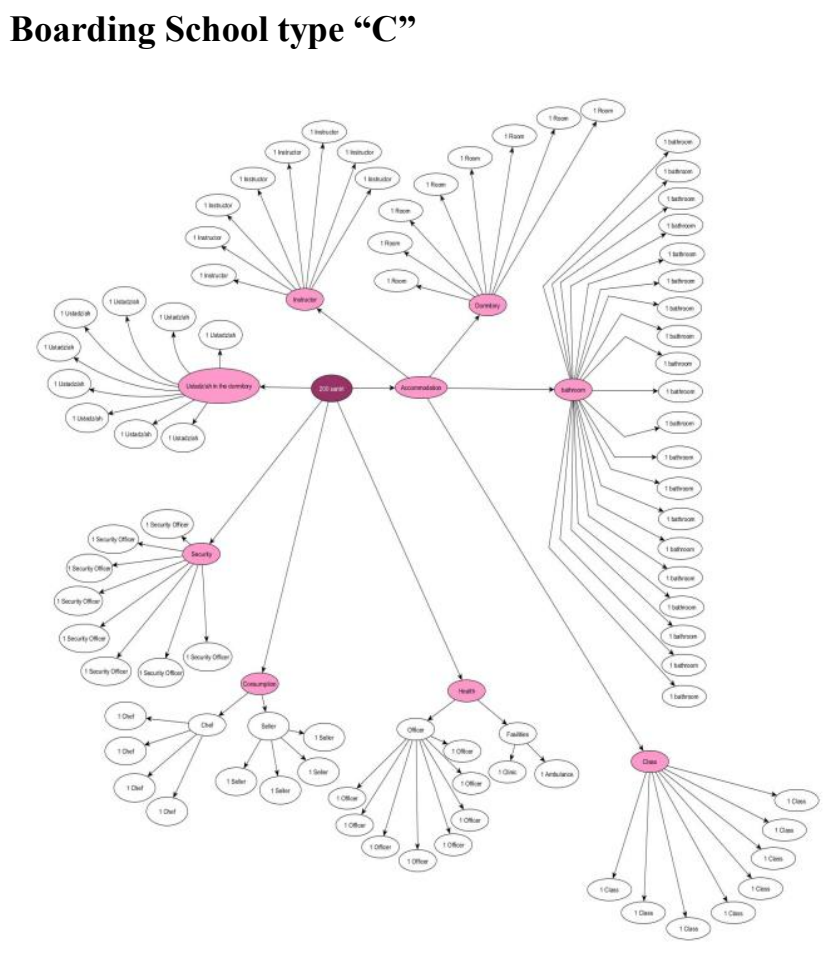

Figure 4. Graph of the growth of boarding school type C.

Based on graph 3 in figure 4. The growth of boarding school type $\mathrm{C}$ with the increasing number of students is as much as 51-200 students also increased facilities provided. Starting from accommodation, teaching, health, safety and consumption. For accommodation increased to 20 bathrooms and 10 beds, in type $C$ the hostel already has buildings for santri's beds. There are 9 lecturers. In the health sector for facilities there are 1 ambulance and 1 clinic, and for health workers there are 10 officers. Whereas in the security sector there are 10 security officers. And finally the type $\mathrm{C}$ has consumption, for consumption itself provides 3 cooks and allows 2 sellers to enter the dormitory environment.

So the ratio formed in this type is as follows:

1. The ratio between bathroom accommodation and students is $1: 10$.

2. The ratio between bed accommodation and students is $1: 20$.

3. The ratio between teachers and students is 9: 200 .

4. The ratio between medical personnel and students $1: 20$.

5. The ratio between health facilities and students is 1 : 100 .

6. The ratio between security officers and students is $1: 20$.

7. The ratio between cooks and students is 3:200.

8. The ratio between traders and students is $1: 100$.
From this ratio in type $\mathrm{A}, \mathrm{B}, \mathrm{C}$ produces the formulas:

$$
\begin{aligned}
& \text { Amount of bathrooms }=\text { roundup }\left(\frac{\text { total santri }}{\text { total bathroom capacity }}\right) \\
& \text { Amount of classes }=\text { roundup }\left(\frac{\text { total santri }}{\text { total class capacity }}\right) \\
& \text { Amount of rooms }=\text { roundup }\left(\frac{\text { total santri }}{\text { total room capacity }}\right) \\
& \text { Amount of teachers }=\text { roundup }\left(\frac{\text { total santri }}{\text { total teacher capacity }}\right) \\
& \text { Amount of chef/cooks }=\text { roundup }\left(\frac{\text { total santri }}{\text { total chef capacity }}\right) \\
& \text { Amount of seller/traders }=\text { roundup }\left(\frac{\text { total santri }}{\text { total seller capacity }}\right) \\
& \text { Amount of health facilities }=\text { roundup } \\
& \left(\frac{\text { total santri }}{\text { total health facility capacity }}\right) \\
& \text { Amount of health officers = roundup } \\
& \left(\frac{\text { total santri }}{\text { total health of ficer capacity }}\right) \\
& \text { Amount of security officers = roundup } \\
& \left(\frac{\text { total santri }}{\text { total security of ficer capacity }}\right)
\end{aligned}
$$

Calculation of the number of bathrooms needs is rounding up the results for the number of students with the total bathroom capacity. In the regulations stipulated that the total capacity should not exceed 10 students. In this case the value of 10 will be the maximum limit for each capacity. For example, if the number of students is 200 , then the number of bathrooms needed is 20 . As well as the others, calculation of the needs for the number of bathrooms, classrooms, rooms, teachers, cooks, sellers, health facilities, health workers and security officers is rounding up the results for the number of students with the amount of capacity of each requirement.

\section{CONCLUSIONS}

Based on the results of the study, the growth of boarding schools has an influence on the needs of boarding schools. The growth of Islamic boarding schools can form a pattern. The pattern is modeled to estimate the needs of Islamic boarding schools. The pattern of needs of this Islamic boarding school can be analyzed using the Cellular Automata method. Based on the results of research and discussion conducted using the national minimum standard reference boarding schools, the results obtained that the number of students (santri) influence the needs of boarding schools, from increasing teaching staff, health workers, consumption, security personnel and increasing infrastructure facilities such as classrooms, health facilities and security. 


\section{ACKNOWLEDGEMENTS}

Thanks the authors say to Allah SWT and all participants who have supported and helped this research. We would like to thank Bp. Muhammad Ainul Yaqin, our lecturer who provided ideas and was patient in guiding us. We would like to thank Mbak Ina et al who have helped us find references related to our research.

\section{REFERENCES}

Ainul Yaqin, M., Majid Muqtadirul, Fiuca Fradana, Fikri., Rizal Mustofa, Muhammad. 2019. Pertumbuhan Model Proses
Bisnis Pada Permainan Hay Day Menggunakan Metode Regresi. UIN Maulana Malik Ibrahim Malang. 7: 154-158.

Geosimulation: Pemodelan dan Simulasi Spasial untuk Prediksi Perkembangan Wilayah dan Perubahan Lahan berbasis Sistem Informasi Geografis dan Cellular Automata. Pengantar Cellular Automata dan Perkembangannya. Institut Teknologi Sepuluh November. Surabaya.

Slimi, R., El Yacoubi, S. 2014. Spreadable Cellular Automata: Modelling and Simulations. Intenational Journal of Systems Science. Vol. 40, No. 5, May 2009, 507-520.

UU Kementrian Agama No. 3 Tahun 1979.

Welsh Assembly Government. 2003. National Minimum Standards For Boarding Schools. Minister for Health and Social Services. 